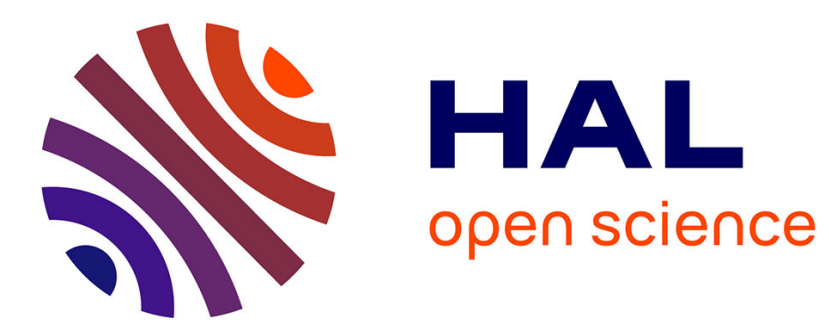

\title{
New spouse, same chores? The division of household labor in consecutive unions
}

\author{
Miriam Beblo, Anne Solaz
}

\section{To cite this version:}

Miriam Beblo, Anne Solaz. New spouse, same chores? The division of household labor in consecutive unions. Socio-Economic Review, In press, 10.1093/ser/mwy014 . hal-01892938

\section{HAL Id: hal-01892938 \\ https://hal.science/hal-01892938}

Submitted on 24 Oct 2018

HAL is a multi-disciplinary open access archive for the deposit and dissemination of scientific research documents, whether they are published or not. The documents may come from teaching and research institutions in France or abroad, or from public or private research centers.
L'archive ouverte pluridisciplinaire HAL, est destinée au dépôt et à la diffusion de documents scientifiques de niveau recherche, publiés ou non, émanant des établissements d'enseignement et de recherche français ou étrangers, des laboratoires publics ou privés. 


\title{
New spouse, same chores? \\ The division of household labour in consecutive unions
}

\author{
Miriam Beblo \& Anne Solaz*
}

\section{Summary (150 words)}

This paper investigates domestic sphere investments, i.e. housework and childcare time, of spouses in two consecutive relationships and aims to identify potential sources of variation. Economic reasoning would predict a learning effect from one partnership to the next, and hence less specialization in the domestic sphere in the second relationship. Prevailing gender norms or institutions, on the contrary, may prevent such adjustments in the division of housework. In a fixed-effects regression analysis with the German Socio-Economic Panel, we compare time allocations of couples whose members experienced two consecutive partnerships from 1991 to 2012. Our results indicate that women's and men's successive matches differ from each other. Women and their new partners tend to reallocate time from housework to childcare while men's individual domestic investment patterns remain similar across unions. Highly educated women conform most to the economic rationale by reducing their marital investments significantly in their next partnership.

Key-words: time-use, housework, work division, divorce, remarriage

JEL classification: D13 - J12

*Correspondence:solaz@ined.fr

Published

Beblo, M., \& Solaz, A. (2018). New spouse, same chores? The division of household labor in consecutive unions. Socio-Economic Review. 


\section{INTRODUCTION}

Divorce and remarriage have become standard life events in developed countries. While divorce rates have remained at high levels in the US and Northern Europe, including the UK, by the 2010s, they are still increasing in Southern and central European countries. Germany's divorce rate has reached 2.3 divorces per 1,000 residents (Eurostat, 2014). A large proportion of separated individuals are likely to re-enter relationships. In 2012, about 24 percent of marital spouses had been divorced already, whereas this figure was only 16 percent in 1980 ( $\mathrm{BiB}, 2014)$. In addition to the upswing in formal divorces, the number of non-marital union dissolutions has also risen. As a consequence, union dissolution is becoming increasingly common; people now more often experience several unions during their lifetime. This demographic pattern of serial partnerships may change the structure of the remarriage market and marital specialization behaviour within couples.

First, the market for remarriages appears less rigid and much larger today than in decades past. With the rising number of union dissolutions, divorcees and stepchildren are now less stigmatized. One consequence of this trend is that this outside option is becoming a more plausible threat to an existing partnership. Second, as the notion of 'marriage for life' is becoming somewhat antiquated, investments during marriage, particularly in the domestic sphere, are increasingly less likely to yield long-term returns. This is because, contrary to marketable human capital, part of the marriage-specific skills acquired through work division during one partnership might not be transferable to a subsequent one (Chiswick and Lehrer, 1990), and may then be lost for the individual in case of disruption.

It is this paper's aim to investigate whether time investments in the domestic sphere differ between two consecutive partnerships. Very little is known about individuals' time allocation in successive partnerships up to now-whether they share common tendencies or whether they differ, particularly with respect to work division. Do spouses exhibit the same patterns of marital specialization in their first and second (marital) unions and, if so, what are the determinants?

We will outline two lines of reasoning in the next section: On one hand, the risk of dissolution might be more present in marriages that involve a divorced or separated partner. According to family economic models, which assume individuals to be forward-looking and utility-maximizing agents, remarried partners would be more reluctant to re-invest in non-marketable, marriage-specific skills since they are more conscious of the risk of dissolution and the detrimental effect of housework specialization on their earnings potential. According to a gender norms approach, on the other hand, the gendered division of housework may simply reflect women's and men's prescribed societal roles and explain women's overproportional investment in domestic tasks. If individual behaviour is strongly determined by these norms, 
and supported by institutions in the same vein, there is no reason why marital specialization should change from one union to another.

The growing population of those who live in at least two partnerships is a specific, but nonetheless very interesting one, from an economic and a sociological perspective. To date, the analysis of work division in consecutive unions has been very limited, mainly due to the lack of data that allows researchers to follow individuals across households, i.e., from one dissolved household to a newly formed. Most research relies on cross-sectional time-use data, comparing individuals in their first union with other individuals in later partnerships. Obviously, this approach suffers from selection and unobserved heterogeneity problems, leading to possibly biased results. The German Socio-Economic Panel (GSOEP) is a unique data source that allows us to observe the domestic investments of the same individual over time by following respondents even after household dissolution and reporting their marital and cohabitation histories, complete with detailed information on both their former and current partners. Using fixed effects models that capture heterogeneity across individuals, we are thus able to identify the "pure" effect of partnership rank on the division of domestic work. Moreover, given the very different consequences of marital dissolution for men and women and the lack of studies that offer comparisons between first and subsequent partnerships, we also investigate whether women's second unions differ from men's second unions. Additionally, we examine the specific role of educational attainment.

Our study produces four main results. First, marital specialization patterns remain rather stable in consecutive unions, particularly in those of men; a finding that confirms the strong influence of gender norms or explicit institutional constraints in preventing individuals from deviating from their assumed social roles. Second, male and female higher-order partnerships differ by their types of matches, as does the division of labour between the two. Third, time transfers from housework to childcare are observed for female second unions. Finally, we observe a time-use adjustment of higher-educated women who significantly reduce domestic investments in their second unions compared to their previous ones.

\section{THEORETICAL CONSIDERATIONS}

Why should the division of housework differ between unions? As discussed above, the reasons are manifold and stem from perceptions about union stability, the role of resources, gender norms and institutions, and different matching processes.

Threat point and learning effects

The first union may be seen as a marital apprenticeship period for individuals during which at least one partner acquires some marriage-specific capital (e.g., learns how to organize the household and 
accommodate the partner's preferences, possibly how to raise children). After a separation, these investments in household production will, at least partially, be lost; in particular, those which concern the previous partner (adaptation to his/her tastes and preferences). Consequently, individuals may exercise more caution and be more reluctant to specialize in domestic tasks in their second partnerships when considering the potential risks of relationship failure.

As a consequence, the possibility of divorce may discourage the specialization and accumulation of marriage-specific capital, as Becker et al. (1977) have argued. Manser and Brown (1980) and McElroy and Horney (1981) proposed Nash bargaining models of the household, in which separation or divorce are possible threat points to an existing partnership that may impact current time-use decisions and the way in which partners allocate and share their time between professional and market activities. In the dynamic bargaining models of Ott (1992) and Konrad and Lommerud (2000), the threat point is endogenously determined by past decisions such as specializing in non-marketable domestic work. Focussing on the strategic aspect of such a threat point, we ask whether partners allocate and share their domestic time differently in second partnerships since they are more aware of the associated consequences. The threat point could play a greater role in later unions than first ones because it has become a more plausible scenario for both the individual who dissolved the relationship and the partner who typically knows that the other person has already experienced a breakup prior to the current relationship. Sullivan (1997) described this phenomenon of a higher anticipated risk of divorce with the expression, "Once bitten twice shy." In the same vein, Aughinbaugh (2010, p. 1174) argues that "the failure of household production to bring returns upon the end of a previous marriage may make women less likely to reduce their labour supply in second and higher marriages." Consequently, they should be evenly unlikely to increase their domestic work.

Another possible rationale would be that people try to reduce the risk of divorce by investing more in the relationship and in marriage-specific capital as soon as they are not the main provider of resources. We should then observe different effects by (potential) earnings and, possibly, by sex as women are more likely to be the second earner.

\section{Relative resources and gender (norm) effects}

Probably the most persistent force in time-use behaviour is the traditional norm of a gendered division of work, as strongly indicated by the universal gender gap in reported time spent on housework in the international literature (Hook, 2010). Many theoretical explanations have been advanced. The theory of relative resources proposes that the balance of power will favour that partner who contributes more resources to the marriage (Blood and Wolfe, 1960; Sullivan and Gershuny, 2012) and allow the wealthier 
partner to do less housework. In a similar vein, the economic dependency approach (Brines, 1994) suggests that housework is mainly performed by women because of wives' economic dependency upon their husbands. The time availability perspective focuses on time allocation between market activities and domestic activities among partners, suggesting that, as women spend less time on market work, they devote more time to housework (Hiller, 1984). Lastly, the doing gender or gender norms theory ${ }^{1}$ may lead female and male partners to allocate their time according to perceived expectations in their proper roles as wife and husband (or mother and father, respectively) (Brines, 1994; Cooke, 2006).

Whatever the theoretical explanation, there is no reason to expect the predicted division of labour to differ across unions as long as we control for indicators of bargaining power, such as the individual wage, in the current partnership.

\section{Institutions}

A third force that may drive specialization behaviour in consecutive unions relates to the institutional background of marriage (or cohabitation) and divorce (or separation). Institutional factors may reinforce the division of labour explicitly or implicitly. For instance, joint taxation of married couples and the existence of private transfers such as spouse or child alimony after divorce might partly compensate for the marriage-specific investment and accompanying loss in human capital by the partner who invested in home production. These private transfers constitute a disincentive for the beneficiary to re-enter the labour market in a subsequent partnership so that he/she might adopt the same behaviour as before in order to maintain them.

In Germany, as in most developed countries, eligibility for these private transfers varies based on former marital status. Contrary to child alimony, which exists both for children born in cohabiting and married unions, spouse alimony exists only for formerly married women (unless the child is younger than three years of age). In addition, the incentives for divorcees to remarry typically differ between the former primary wage earner (usually the man) and the partner responsible for the household sphere (usually the woman). This is particularly true and interesting for Germany, where, until 2008, maintenance payment regulation was relatively generous to the lesser- or non-earning spouse. ${ }^{2}$ Since maintenance payments are means-tested and conditional on not having re-partnered, they imply a disincentive for the beneficiary to re-partner. As cohabiting spouses typically do not possess a formal contract and are thus less protected in case of separation, we expect them to invest in less work division than married couples in general which

\footnotetext{
${ }^{1}$ The theory of identity economics rationalizes this behaviour in a utility framework that incorporates the social costs of deviating from one's social role (Akerlof and Kranton, 2000).

${ }^{2}$ As the majority of our sample is covered by this old law, there is no visible effect of the new one in our observation period.
} 
has been widely empirically demonstrated (South and Spitze, 1994). More egalitarian values and senses of equity in each's partner contribution shared by non-married versus married couples (Axinn and Thornton, 1992; Brines and Joyner, 1999) may also contribute to the differences observed. Then, in case of repartnering, we expect a stronger adaptation of time use for cohabiting unions than for married ones because of fewer monetary transfers coming from or going to previous spouses. However, it is difficult to say whether this adaptation will involve less or more investment in domestic tasks in the second partnership as this depends on both the selection of cohabiters who re-partner and also the new partner's characteristics.

\section{New partner matching}

The last and probably most obvious reason why housework division is likely to differ between unions is simply that one partner has changed. The amount and division of work within a couple is the outcome of two persons' preferences and negotiation, and a new partner is likely to have somewhat different inclinations and characteristics.

Becker (1973) advances that greater differences in the relative abilities or skills of the partners will result in complementarities and generate greater gains from specialization. For more diverse couples in terms of education, age, and wages, we should hence observe more specialization. Becker's theory predicts negative assortative matching with regard to spouses' wages in order to maximize the gains from specialization. However, this prediction has found relatively weak empirical support (Zhang and Liu, 2003). We usually observe positive assortative matching, known as homogamy (Nakosteen et al., 2004). Partners tend to match with partners of similar age, educational level, ethnicity, and, consequently, earnings (potentials).

Due to homogamy, the remarriage matching process may allocate a partner very similar to the first one (in terms of socio-economic characteristics). Because of his/her similar characteristics, this new partner is likely to behave similarly to the former one, which includes decisions about time allocation. Aström et al. (2009) find evidence in Swedish register data for high similarity between the successive partners of women who experienced two successive unions. Duncan and Hoffman (1985) also present a positive correlation between the incomes of a woman's two successive husbands.

On the other hand, ample empirical evidence suggests that homogamy decreases from first to subsequent unions because of different matching processes: The re-marriage market is smaller than the first-marriage market (fewer singles available at each age), and individuals looking for a new partner may have to expand their criteria. This compositional effect increases the likelihood of finding someone who 
strays further from one's own characteristics compared to the first partner. Empirical evidence confirms that, for instance, the observed differences in age and educational level are more pronounced in second marriages (Bozon, 1991) and that socioeconomic status plays a weaker role in remarriages than in first marriages (Shafer and James, 2013). It suggests that specialization based on complementarities should be higher in second unions.

Based on these theoretical considerations, we are unable to unambiguously predict whether individuals engaged in a second union would change their specialization behaviour, or whether one partner (generally the woman) would invest less in the domestic sphere than before. Persistent forces such as gender norms and institutions may balance the possible learning and cautiousness effects. In an effort to empirically distinguish the second union effect from other factors, we must take into account the characteristics of the new partner and household composition to capture the couple matching process. If any, we expect the possible reduction of domestic time investment between partnerships to be more pronounced for women than for men. Typically, the woman is the partner who specializes more in domestic and childcare activities, and who consequently loses more in the event of marital disruption in terms of earnings potential. We therefore expect to observe more women adapt their behaviour in the new couple by reducing domestic investments.

Due to their different nature, we will distinguish housework and childcare later on in the analysis. For childcare, the loss of marriage-specific capital after separation is more debatable than for other tasks. There is more likely a loss for the non-custodial parent who has invested in children's education and does not have (regular) contact with them any more after marital dissolution. For the custodial parent, we can assume that parts of the skills are kept. As mothers are much more likely to be the custodial parent, results are expected to be gendered. Separated parents have to share the time spent with the children from their first union, consequently this time may be central to negotiations and valued in and of itself. In addition to stepchildren, individuals may have children with their new partner. For children born in the new partnership, transferability of parental skills might be more difficult if parental skills are child-specific. We may expect different allocation of time between housework and childcare for biological and step parents.

\section{PREVIOUS FINDINGS}

To our knowledge, very few studies have analysed the dynamics of the division of domestic labour within couples. In a longitudinal study for Germany, Schulz (2010) revealed the dynamics of spouses' time use over the course of their relationships. Whereas about half of the couples exhibited an egalitarian 
division of housework at the beginning of the relationship, over time, the arrangements shifted systematically toward a more traditional arrangement. After 14 years of marriage, the great majority of couples $(85 \%)$ had adopted a traditional work division, independent of the spouses' economic resources. Particularly after the birth of a child, the women tended to take over larger shares of household work.

Studies on the dynamics of the division of domestic labour by union order are even scarcer. We counted only three studies in English-speaking countries. Sullivan (1997) used one of the waves of the British Household Panel Survey (BHPS) to show that women's second unions tend to be more egalitarian due to greater male participation, but that men's second unions do not. The study used a question about the total number of domestic working hours devoted to cooking, cleaning, and laundry asked directly to the respondent - very similar to the question used in the GSOEP questionnaire. Another study, by Ishii-Kuntz and Coltrane (1992) in North America, also showed that remarried men participate more in five domestic tasks (cooking, meal clean-up, shopping, laundry, and housecleaning) than men in their first unions. The authors account for family composition and analyse male participation in the following four family types: (1) first married couples with biological children; (2) remarried couples with biological children only; (3) remarried couples with step-children only; and (4) remarried couples with biological and step-children. They find that fathers with only biological children (and not step-children) are those who participate most. They also report that remarried women spend more time on housework, particularly those who have stepchildren. In the most recent analysis, Aughinbaugh (2010) studied women's labour market participation by marital status and marriage order using the U.S. Panel Study of Income Dynamics for the years of 1979 to 2001. After controlling for background characteristics, she shows that women's labour market participation remains stable between first and higher-order marriages, but that hours spent at work differ. In higher-order marriages, women work more hours. However, due to her data set, Aughinbaugh focuses exclusively on women, and only a small proportion of the respondents were in two consecutive marriages $(\mathrm{n}=77)$. In addition, the results differ when unobserved heterogeneity is taken into account, and vary by the form of unobserved heterogeneity. Accordingly, we will pay particular attention to this methodological problem in our analysis.

As the previous literature also shows remarriage patterns to differ by gender (Shafer and James, 2013), we will systematically distinguish between female and male second unions in our own empirical analysis.

\section{METHOD}

The merits of panel data 
Time allocation patterns within couples and the disproportionate female share of housework have been addressed by many economic, demographic, and sociological studies. Most of the empirical specifications are cross-sectional and based on time-use data. The main difficulty of these studies is thus to isolate and eliminate unobserved effects, that have the potential to create selection bias. One reason is that housework division depends on a vast set of determinants, both observed (such as age, household structure, partner's characteristics, or children) as well as unobserved (such as preferences for having a clean home, wearing ironed clothes, or spending time with children). These unobserved factors are difficult to take into account in a cross-sectional approach.

Studies taking a life course perspective on the dynamics of time allocation are still rare (as one exception, see Baxter et al., 2008) and they do not systematically apply models that can account for unobserved heterogeneity. The ideal data source to study couples' time allocation decisions with changing partners are panel data that provide observations of the same individual, and the respective spouse, in different partnerships. With fixed-effects estimation, such data offer a promising approach to control for unobserved individual-specific factors, at least if we assume their stability over time. Of course, the assumption of time-constant unobserved factors may also be seen as a weakness of our model. In case these unobserved factors change over time or across unions and the change is related to an individual's or his/her partner's domestic investments, the second union effect might be estimated with a bias. However, we think that we can reasonably assume individual and parental preferences for having a clean house, home-made meals or concerning children's education to remain stable over time and across partnerships.

\section{Our data}

The German Socio-Economic Panel (GSOEP) is an annual micro-data panel based on annual interviews of individuals and households since 1984 in West Germany and since 1990 in East Germany (Wagner et al., 2007). It is well suited for our analysis as it follows participants over time, even in the case of household dissolution. When a household dissolves, all members of the new household, including any potential new partners, are re-interviewed in their new living circumstances. The GSOEP includes various individual characteristics that are likely to affect both an individual's re-partnering match and intra-family work division. Survey participants provide annual information about their living conditions, household structure, and most relevant for our purposes, their time use. Although not as informative as a detailed time-use survey, the GSOEP has the distinct advantage of collecting longitudinal data, enabling us to obtain a reasonable number of respondents in two consecutive unions within the observation period.

\section{Sample}


Our sample comprises all individuals within the GSOEP dataset who experienced at least two partnerships for which information on both spouses (from the first and second union) are available. For our analysis, we chose an observation period of 22 years, from 1991 to 2012 . We selected all respondents aged 20-60 who reported at least two consecutive partnerships within the observation period, i.e., whose first observed union (whether married or not) was dissolved. The second union did not have to follow immediately, but had to begin at some point during the observation period of the GSOEP. In total, we ended up with 665 individuals who fulfilled these criteria. On average, they are observed for four years in their first union and almost five years in the second. Note that both partnerships may be censored by the observation window - the first union being typically left-censored because the couple had already been formed when entering the panel, and the second union being right-censored by the last year of interview, unless it dissolved immediately after.

\section{The dependent variable}

The time use information is gleaned from a set of items in the GSOEP questionnaire in which respondents are asked to report the average amount of time per day spent on employment, housework, errands, gardening, repairs, childcare, and hobbies or other leisure activities. The questions reads: "What

does a typical weekday look like for you? How many hours per day do you spend on the following activities? 1) job, apprenticeship, second job (including travel time to and from work), 2) errands (shopping, errands, citizen's duties), 3) housework (washing, cooking, cleaning), 4) childcare, 5) education or further training, studying (also school, college), 6) repairs on and around the house, car repairs, garden work, 7) hobbies and other free-time activities." In the years of 1991 to 1997, the wording of the time-use question differed marginally. But the items we are interested in throughout this paper were unaffected.

Hours are reported for weekdays, Saturdays, and Sundays separately by men and women, but annual data is available for weekdays only (weekends are reported bi-annually). For this reason, we focus on weekday time use primarily, but present some descriptive statistics on a reduced sample including both weekday and weekend data. Because a small number of respondents report simultaneous activities totalling more than 24 hours per day, we suspect an overestimation of time devoted to work (both paid and unpaid) for some respondents. We therefore restrict the sum of all work activities to 18 hours per day (thereby allowing at least 6 hours of physical rest) as proposed in Barg and Beblo (2012). Thereby, employmentrelated time is taken as reported (if justified by contracted hours) and the remaining time uses are rescaled proportionately.

In our analysis, we focus on marital specialization in time use by measuring the investment of each partner in the two spheres: paid labour market work and unpaid domestic work. We adopt an indicator that 
takes into account both domains: "Domestic investment (DI)" measures the ratio of hours spent on domestic activities - both childcare $(\mathrm{C})$ and housework $(\mathrm{H})$ to the hours of total work, which equals domestic time plus time spent on employment $(\mathrm{E}): \mathrm{DI}=(\mathrm{H}+\mathrm{C}) /(\mathrm{H}+\mathrm{C}+\mathrm{E})$.

This multifaceted indicator has several advantages. It provides an adequate summary of the relative investment in the domestic sphere. Furthermore, since time allocation decisions for the private and market spheres are performed simultaneously, considering both together helps us to avoid the problem of endogenous employment hours that arises when focusing only on domestic work (Jenkins and O'Leary, 1995). ${ }^{3}$ As the employment status is likely to change over the life-course, our indicator of domestic specialization should comprise both dimensions. An increase in DI means that the person spends more time on unpaid work relative to paid work.

We use a broad definition of domestic work that includes both housework tasks and childcare activities. Housework includes "core chores" such as washing, cooking and cleaning (covered in category 3 of the GSOEP time-use item), shopping and errands (category 2), and repairs and gardening (category 6). Childcare is reported separately (in category 4). To disentangle possible counteracting effects of the two activities housework and childcare, we later on also differentiate between the two sub-indicators DIcc $=\mathrm{C} /(\mathrm{H}+\mathrm{C}+\mathrm{E})$ and DIhw $=\mathrm{H} /(\mathrm{H}+\mathrm{C}+\mathrm{E})$, which together sum up to the aggregate DI.

\section{Empirical strategy}

Our empirical strategy is to estimate the relative domestic time investments for women and men separately. For the reasons outlined above, we want to determine whether the level of women's (and respectively, men's) marital specialization in second unions differs from that of their first, and whether the specialization appears conditional on individual, partner, and/or couple match characteristics. By using a fixed-effects model, we account for all invariant factors, both observed and unobserved, and capture any time-constant heterogeneity between individuals who experience two partnerships. The following model is estimated:

$$
D I R_{i t}=\propto S U_{i t}+\beta R_{i t}+\gamma P_{i t}+\delta C_{i t}+\varepsilon_{i t}
$$

$\mathrm{DIR}_{i t}$ is the respondent's (the wife's or the husband's) relative domestic time investment observed each year (or one of the two sub-indicators, respectively). $\alpha$ is the coefficient of interest that estimates the

\footnotetext{
${ }^{3}$ Note that complete specialization with a null involvement in one of the two spheres proves negligible in practice.
} 
effect of being observed in a second union $\left(\mathrm{SU}_{i t}\right), R_{i t}$ and $P_{i t}$ are two sets of time-varying explanatory variables for the respondent and partner, and $C_{i t}$ is a set of time-varying covariates for the couple/match.

We decompose the error term $\varepsilon_{\mathrm{rt}}$ in the following way:

$$
\varepsilon_{\mathrm{i} t}=\theta_{\mathrm{i}}+\mu_{\mathrm{i} t}
$$

The fixed-effect term $\theta_{\mathrm{i}}$ is the unobserved, individual-specific component that assesses the respondent's unobserved heterogeneity and $\mu_{\mathrm{it}}$ is assumed to be a random variable with a normal distribution with a mean of 0 and a variance of $\sigma^{2}$.

The partner equation looks symmetrical except that the union rank and the individual fixed effect correspond to the respondent's. Once we account for fixed effects in the individual observed in both partnerships, the regression offers an indication about the changing behaviours of the new partner, compared to the previous one. If $\propto$ is significantly different from zero, it means that the new partner has a different level of domestic investment to the previous one, all other things being equal.

$$
D I P_{i t}=\propto S U_{i t}^{r}+\beta R_{i t}+\gamma P_{i t}+\delta C_{i t}+\varepsilon_{i t}
$$

We introduce the time-varying explanatory factors step by step in order to distinguish different levels of explanation: the individual effect, the partner effect, and finally, the couple match effect. Model 1 only takes into account the union order and time-constant individual controls through $\theta_{\mathrm{i}}$ in a fixed-effect specification. Model 2 adds time-varying respondent characteristics $R_{\mathrm{it}}$ (age and hourly potential wage). To account for the endogeneity of wages ${ }^{4}$, we calculate a potential Mincer-type wage for those not employed, i.e., a proxy for the wage they may expect if they were to re-enter the labour market, based on the individual's job history and real work experience (including years of schooling, age, actual experience, squared experience, nationality and distinguishing between part-time and full-time positions). Note that a sensitivity analysis, where we condition on the Mincer input variables (schooling, experience etc.) directly, instead of using imputed potential wages, yields similar results. The third specification (Model 3) adds the partner's characteristics $\left(P_{\mathrm{i} t}\right)$, whether first or second, with respect to age and potential hourly wage. Finally, Model 4 includes the matching and couple covariates $C_{i t}$ such as non-labour household income, dwelling size, number of children per age group (below 3, 3-5, 6-11, and 12-16 years of age), the presence of stepchildren, and the formal marital status. Unfortunately, our data do not allow us to calculate the precise couple duration for first couples due to possible left censoring (if they formed a couple before entering the first GSOEP interview) and because we have no information on the exact year of couple

\footnotetext{
${ }^{4}$ As those who decide to spend their time on only unpaid activities, being housewife for instance have null wages.
} 
formation for unmarried couples. However, we are able to calculate an "at-least duration" that we use as a further control variable. Due to rather persistently different gender role models in terms of female labour force participation and female preferences for work in West Germany and East Germany (which used to be the GDR, German Democratic Republic) (Cooke, 2006; Beblo and Görges, 2016), we also include a dummy for residence in East Germany which serves as a shift parameter.

\section{RESULTS}

\section{Descriptives}

Figure 1 displays our domestic investment indicator during the last years of the first observed partnership (left panel) and the initial years of the subsequent one (right panel), separately for female and male partners. The illustration does not consider the time elapsed between separating and re-partnering.

\section{Insert Figure 1}

The distances between the curves indicate large gender gaps in relative investments, with higher relative levels of domestic investment for women than for men. Women spend more than half of their total work time in domestic and parental activities, whereas men do this only one third of their total time, devoting the remaining two thirds to labour market activities. At first glance, our sample reveals a remarkable similarity in the work division of couples between first and second unions. We are inclined to interpret an increasing tendency toward domestic specialization for both men and women in their second partnerships, though, which possibly coincides with the arrival of children in the new couple. With regard to first unions, domestic investments are rather stable for men, while they decrease slightly for women. The decrease in domestic investment during the union's last years, in view of separation, may be an indication of an anticipated divorce or dissolution (Johnson and Skinner, 1986). Further data analyses unveil that the decrease is due to both a reduction of domestic hours as well as an increase in women's labour force participation.

As illustrated in Tables $1 \mathrm{a}$ and 1b, first and second unions also differ at both the individual and couple levels with regard to other socioeconomic characteristics that may be directly or indirectly linked to the observed time use. Female (and respectively, male) respondents' columns correspond to individuals who experienced at least two consecutive unions (called first and second one) and were surveyed in both partnerships. Columns of the male (female) partner describe the characteristics of the respondents' respective partners (for whom we do not have information on the number of previous partnerships). 
Housework hours slightly decrease while childcare time increases between women's consecutive partnerships (Table 1a), leading to a rather stable time investment devoted to the domestic sphere. The indicator of domestic investment increases only slightly (from 0.53 to 0.57 ), primarily due to the reduced number of hours spent in the labour market. For men (Table 1b), the increase of the domestic investment indicator (from 0.29 to 0.36 ) is driven both by a decrease in market hours and an increase in housework hours in their second partnership. Neither change is statistically significant though. Note that the domestic investment indicator for the full week (including also weekend time use) ${ }^{5}$ resembles the one for weekdays only, at least in relative terms. Not surprisingly, all respondents - both, women or men, respondents or partners - devote more time to household and parental activities and less to market work on weekends. The gender gap in full-week domestic investment is reduced, but remains substantial. The indicators of first unionists range between 0.39 (men) and 0.58 (women). Weekend domestic time has somewhat more weight in second unions, letting the whole indicator rise by 8 to 9 percentage points for both sexes.

With respect to other characteristics, individuals in their second partnerships are, on average, of course, older, and slightly more likely to be highly educated (also due to more potential time spent pursuing education). Furthermore second union partnerships are less likely to be married and are observed during a longer period. Partly because of these life cycle effects, they are also more likely to be well-off, with higher non-labour income and larger average dwelling size.

\section{Insert Tables $1 a$ ad $1 b$}

Interestingly, women's second unions differ from those of men in several respects. The remarriage market characteristics hence appear to be gender-specific. For instance, spouses in women's second partnerships show more similarities than spouses in men's second partnerships. The age gap between spouses in female second unions is smaller (1.5 years) than in males' (more than four years). The hourly gender wage gap (predicted for those out of the labour force) is also smaller in women's second unions but higher in men's. Furthermore, women's second households tend to be larger and inhabited by more children above age 6 ( 0.34 versus 0.21 for children aged 6 to 11 , and 0.24 versus 0.19 for children above 11 ), presumably because it is the mother who typically has custody of the child(ren) born in the first union. This may also be why women spend more time providing childcare in their second unions, whereas men's respective hours decrease.

\footnotetext{
${ }^{5}$ As said above, every other year the GSOEP respondents are interviewed about their Saturday and Sunday use of time in addition to the weekday activities. We calculate a weighted (respectively 5/7, 1/7 and 1/7) daily average for all individuals with complete time use information.
} 
These multidimensional differences between first and second unions by gender and the theoretical impact of the partner match can only be fully accounted for by a multivariate regression analysis on separate samples, according to whose partner (the man's or the woman's) is experiencing a second union.

\section{Estimation results for domestic time investments}

Tables 2 and 3 document how women's and men's domestic time use in their second unions varies with the inclusion of time-varying explanatory factors step by step in order to distinguish different levels of explanation: the individual effect, the partner effect, and finally, the couple match effect. As the dependent variable we first look at the aggregate domestic investment indicator and will later distinguish between the relative time investments in childcare and in extended household work.

According to the estimation results in Table 2, women increase their domestic investments when they re-partner (Model 1). In the fixed effects specification, the estimated increase $(+0.06)$ is larger than the raw gap displayed in Table 1a (+0.04) that was underestimating the true behavioural adjustment in a second union. The rise is robust to adding her individual characteristics (age and potential wage, in Model 2) as well as her partner's characteristics (Model 3). However, the second union effect is no longer statistically significant when taking the compositional characteristics of the couple into account (Model 4). This means that women's higher participation in the domestic sphere during their second union is primarily explained by the different household composition, with the number of children being most important, followed by marital status and non-labour income level.

Women's consecutive partners do not seem to exhibit different behaviours of specialization either. Once we control for the woman's characteristics, the coefficient of the second union no longer proves statistically significant. The women do not appear to choose more egalitarian-minded men than before, presumably because the remarriage market process is driven by other (e.g., financial) factors. Remarriage seems to be a way to overcome financial difficulties for some women (Dewilde and Uunk, 2008), at the cost of increased engagement in the domestic sphere.

These results show that women in second unions are not investing less time in marital-specific skills than before, which seems to contradict our first economic hypothesis that they might adjust their specialization behaviour after the first union. Although the second union effect sums up different theoretical channels which may all be operating at the same time, the estimated net effect seems to give more support to the gender display and institutions argument. The latter compels individuals to maintain similar behaviour in subsequent partnerships in spite of a changed partner match. However, our findings may also be an indication that women are holding to their once chosen work division, trying to make economic use of their past marital specialization investments. 


\section{Insert Table 2}

Table 3 shows similar results for men. Like women, they do not seem to change their domestic investments from one union to the next. The coefficient estimate of the second union union-which is statistically significant and positive in the first specification (without any controls) —is no longer significant once basic individual characteristics are considered. Like women, men seem to adhere to the same time use pattern in their first and second unions and their respective partners also exhibit similar levels of domestic investment.

\section{Control variables}

Concerning individual, partner, and couple background characteristics, we first notice that the variation of domestic time use decisions remains largely unexplained for men, as documented by the weak explanatory power of $\mathrm{R}^{2}$, well below 10 percent. In contrast, the factors that affect the domestic investment of women seem somewhat better determined, since about 30 percent of the variance in the dependent variable can be explained by the variables included in the richest specification in Model 4. This applies to both the female respondents' and female partners' models. According to Tables 2 and 3, these are, most importantly, marital status and the presence of children-with the youngest associated with the largest increase in women's unpaid domestic work relative to paid market work. Being married is also positively associated with a more traditional division of work between spouses, with the woman investing more in the private sphere. Economic variables seem to influence women's decisions to invest more in the domestic sphere than the labour market. The partner's wage level is positively related to a higher domestic investment of women (for female respondents in Table 2, as well as female partners of male respondents in Model 3 of Table 3), consistent with household bargaining theory, as is the non-labour income (Model 4 in both tables). These monetary resources may pose a disincentive for women to invest in the labour market. Couple duration is not significantly related to domestic investments, although the signs are the expected ones. The more years a couple is observed the more household time tends to be invested by the female, and the less by the male.

\section{Insert Table 3}

With regard to the male partners' participation in domestic work in women's second unions, the estimates of Model 2 (Table 2) indicate that it is largely and positively related to her age. This relationship also proves robust with the introduction of further controls in Models 3 and 4.

For male respondents in Table 3, his age, family composition, dwelling size, and non-labour income show some correlation with domestic time use. In a fixed effects specification the respondent's age may of course also partly pick up the time elapsed between the two unions. We will further investigate this 
aspect in the heterogeneous effects section. A larger dwelling size is associated with reduced domestic investments, which might be explained by a wealth effect. Wealthy men are more likely to both outsource household work by buying substitutes on the market and work longer hours in their jobs. Table 3 also confirms that the female partner's own potential wage diminishes her relative participation in domestic and parental work. This effect may be interpreted in connection with the relative resources or economic dependency approach or in a bargaining context, where the woman's bargaining power regarding financial resources is negatively related to her domestic investments. On the grounds of the former GDR, men are more engaged in household activities, as expected and indicated by the significantly positive coefficient for the East Germany dummy (which is identified by movers from West to East). Finally, the number of stepchildren in the household does not seem to affect either spouse's domestic investments in any scenario.

\section{Differentiation of domestic time investments}

To distinguish between the time invested in childcare and that one spent on extended household work we now study the results of a regression analysis of the indicators DIcc and DIhw separately (Table 4). We choose our final and preferred Model 4 to investigate whether childcare and housework

investments are affected differently when entering a second union. As both single indicators sum to the former aggregate one, we can interpret the coefficient estimates of the second union dummy variable as a decomposition of the aggregate estimate. The differentiation reveals a significantly increased time share for childcare in women's second unions by both, the woman as well as her new partner. While she raises childcare hours by six percentage points, the new partner's share is three percentage points larger than the predecessor's. In the aggregate, however, this increase is almost (more than) offset by her (his) diminished housework time in the new partnership. The shift from housework to childcare by women in subsequent partnership supports the economic model predictions according to which childcare might be less marriagespecific than housework. It is also in the line with recent findings of childcare substituting housework (Gimenez-Nadal and Sevilla-Sanz, 2012) in response to the increase of female paid work, showing that time with children is becoming an investment for parents. This could be even more the case after a separation. Male second unions seem to draw the same picture, as the effects have the same signs but none of them is statistically significant, though.

\section{Insert Table 4}

\section{Heterogeneous effects}

An important shortcoming of the fixed effects model is that any time-invariant characteristics at the respondent level are, by construction, excluded from the model as explanatory factors. In order to assess possibly heterogeneous effects of second partnerships on domestic time use, we now study interaction 
effects. ${ }^{6}$ We add interaction terms for sub-populations in our final and preferred Model 4 to analyse whether these groups react differently when entering a second union. In particular, we interact the union rank with (1) marital status of the first partnership, (2) children in the first partnership, (3) time elapsed after dissolution of the first and formation of the second partnership, and (4) both partners' educational attainments.

As illustrated in Table 5, three of the four interaction analyses for women reveal a statistically significantly different change in time use from first to second union between the subgroups. Non married, childless or middle-to-low-educated women show a significant increase in their time devoted to childcare, whereas the respective counterparts do not, since their interaction effects almost totally offset the basic second-union estimate. That is, married women, mothers or high educated do not adjust their childcare across unions. Hardly any differences between the groups can be observed for housework investments. The results for men are qualitatively similar, but most of them smaller in size (see Table 6). We now discuss each interaction in more detail.

In regard to marital status, while the amount of childcare depends on the previous status, the amount of housework remains unchanged for all women in their second unions. We might have expected domestic investment behaviour to change according to marital status, given that some private transfers such as spouse alimony are only available to formerly married spouses. The fact, that we observe no difference between married and non-married partners, suggests a continued gender display across any unions. For men, we observe a reduction in housework time when formerly unmarried and no change when married.

Our second interaction considers whether the first union had children or not. Re-partnered women invest relatively more time in childcare than they did in their first partnership if children had not been present already. The same behaviour can be observed for men. Mothers, on the contrary, are not affected by the second union status (the basic estimate of 0.75 is completely offset by the interaction estimate of 0.78), while fathers cut back on childcare once they re-partner.

The third interaction concerns the elapsed time between the marital dissolution and the new couple formation, which might be an indicator of the difficulties in finding a new partner or the increased expectations regarding the right match. The estimates reveal that only men who have waited longer than three years to re-partner do more childcare during their second unions, whereas no significant difference between unions is observed for women or men who re-partner earlier.

\footnotetext{
${ }^{6}$ Another way is to split the sample and perform separate estimations. We did both and results are similar.
} 


\section{Insert Tables 5 and 6}

Our fourth interaction concerns educational attainment. A very interesting result appears, as highly educated women (i.e., with a university degree) perform significantly less domestic tasks than women with a secondary or primary education level. While the low educated women spend more time with childcare when being re-partnered (highly significant coefficient estimate of 0.048), the high educated do not change their behaviour (the basic estimate is offset by the interaction term). Furthermore, both groups step back on housework, but high-educated women reduce their investments to a much larger extent. The low educated may face difficulties in returning to the labour market or increasing their paid work time, whereas highly educated women may have to extend their labour force participation and cut back on unpaid work. Previous studies confirmed that many women who had not been in the labour force re-enter the labour market after a separation, which pays off mostly for the highly educated (Finnie, 1993; Bonnet et al., 2010). Most importantly, high-educated women are those who bear the highest opportunity costs by specializing in the domestic sphere instead of supplying labour to the market. They may have already perceived these costs during their first union and are consequently more cautious in their second.

\section{DISCUSSION AND CONCLUSION}

One well-known and puzzling finding in the economic literature of time use and the division of housework is that women with higher human capital endowments than their husbands (as indicated, e.g., by their higher education levels or wages) continue to perform more domestic work than their husbands, even if they work full-time. This paradox has been explained by the doing gender theory (West and Zimmerman, 1987) and the concept of identity economics (Akerlof and Kranton, 2000), the economic equivalent, in which women bear a social cost of escaping their prescribed gender roles and therefore do not necessarily maximize monetary utility when making a time use decision.

The present study points out a puzzling new fact. According to Becker et al. (1977), spouses are more reluctant to invest in marriage-specific capital when they anticipate a marital dissolution. Using panel data on couples' time uses across unions, we are able to compare domestic investments — measured as unpaid work relative to total (paid plus unpaid) work - throughout an individual's marital history. When controlling for respondents' unobserved heterogeneity by individual fixed effects, we find that, in the aggregate, marital investment behaviour does not differ from a first to subsequent partnership in Germany. In particular, we find that men choose the same level of marital investment with their next partners. This result persists even if we disaggregate total household work into childcare and housework. 
We expected to observe more women adapt their behaviour in the new couple context by reducing domestic investments as it is typically the woman who had specialized more in domestic and childcare activities in a previous relationship, and who had consequently more to lose in the event of marital disruption in terms of earnings potential. Our analyses confirm a gender pattern, though not exactly the way we expected: women, who invested in marital specific capital during their first unions, bearing possibly high costs in the event of couple dissolution, choose the same level of marital investment with their next partners overall. Interestingly, they invest relatively more time in childcare, i.e., they reallocate time from housework to childcare.

As laid out in the theoretical section, we also expected a stronger adaptation of time use for cohabiting unions than for married ones in case of re-partnering, because of fewer (legally enforceable) monetary transfers from or to a previous spouse. Our findings provide no support for this hypothesis.

The overall non-adaptive behaviour of women is puzzling since bargaining theory and learning would predict women to be more aware of the possible risks involved when re-partnering. After all, there does not seem to be a learning effect from the first marital experiment; or if any, it is compensated by counteracting effects, leading to rather constant time allocation across successive couple unions. The stability of domestic work division is due to persistent forces that influence all partnerships, independent of rank order. First, individual preferences regarding the share of domestic activities may just be strong and remain stable across consecutive partnerships to maintain domestic investments. Second, if society's or the peer group's role assignments to genders are very strong, and this applies to all couples uniformly, behaviour is not expected to change between first and second partnership. Finally, institutions (e.g., spouse alimony) may help to attenuate the costs of divorce, particularly for the person specializing in domestic work, who is then willing to re-invest in later unions.

For men, specialization behaviour appears particularly stable from one union to the next. Hence, from the couple's point of view, our results suggest that a second partnership's division of work between spouses is just as balanced (or unbalanced) as the previous one.

The rare papers that have studied this question provided rather ambiguous results that may have only partly been due to country specificities. Whereas Sullivan (1997) found more egalitarian second unions in terms of housework division in the UK, and Aughinbaugh (2010) showed that American women increase their market labour hours when they re-partner, Ishii-Kuntz and Coltrane (1992) countered that remarried women in the U.S. spend even more time on housework. However, these past results share the caveat of being either based on small sample sizes or cross-section data sets that do not fully account for 
individual unobserved heterogeneity, which is potentially of great importance when studying marital behaviour.

Our panel-data results provide strong evidence for persistent marital specialization patterns between individuals' consecutive partnerships, with only some subgroups exhibiting distinct behaviour. Particularly high-educated women reduce their relative domestic time investments in their second relationships. We interpret this as resulting from their higher opportunity costs of labour market time. Women with high educational attainment who specialize in the domestic sphere simply have more to lose than those with less education. Consequently, they increase their labour force participation-which might also be easier for them than for lower-educated women - and/or reduce their housework hours, but not their childcare hours, when re-partnering.

The observed increase of childcare time in female second unions is probably driven by the fact that the custodial parent is most likely to carry on the parental tasks from the previous union (initially shared between both parents). However, this increase in childcare time, which is also observed for the women's new partners, may also be due to an increasing trend in parental tasks observed in recent decades. While women tend to work more in paid employment, the time devoted to children has not fallen (Fox et al., 2013). The re-allocation from housework to childcare in second unions is an additional proof that parental activities are highly valued today and seem to be preserved.

In spite of the unambiguous results, some limitations of our study should be mentioned. First, as housework, childcare, and employment hours are self-reported in the GSOEP and taken as weekly averages, they are certainly less precise than time-use diary information would be. However, we have no reason to believe that a potential bias would affect time use information differently across unions, so this caveat does not present a major concern in our analysis. The second limitation refers to our aggregate measure of relative domestic investments that we use to overcome the inherent problem of circularity between private and labour market spheres. The indicator includes working hours in both the domestic and labour market sphere, so that any changes may be due to an adjustment of housework time, childcare time, paid work time, or all. In this sense, our study draws a rather broad picture, though, by further distinguishing between relative childcare and relative housework investments, we have already gained some insight into individuals' time use trajectories across unions.

Finally, concerning our data, we have to mention two limitations. First, by comparing only individuals who experienced two consecutive partnerships, we did not take into account the potential selection bias of those who re-partnered. As pointed out by Ruggles (1999), the financial autonomy of women accompanying the expansion of female employment has not only allowed women to divorce but 
also to remain divorced. Divorcees who decide to re-partner are possibly different from others. Along the different educational patterns between whites and blacks Smock (1990) showed that those forces that may push more disadvantaged groups to reform a couple may as well be offset by their lower opportunities on the remarriage market. Particularly those women with more (financial) autonomy might then opt for staying alone, for waiting longer to find a suitable new spouse, or for having a LAT relationship for instance. This may be one explanation why we do not observe a more egalitarian sharing of domestic work in second marriages, for instance.

Second, our panel fixed effects approach control only for time-constant unobserved heterogeneity . It involves the crucial assumption of constant individual preferences over time and across unions. However, if changes in preferences are in fact responsible for marriage dissolution, or if one partner adjusts his or her behaviour to please the new partner, this would imply finding behavioural adjustments. The overall absence of behavioural changes in our analysis thus suggests not only the strong role of gender norms and institutions but may also be due to persistent individual preferences. The reluctance to adjust time use in the couple, which had been known already from the housework gender gap not adjusting to rising female labour force participation, is particularly noteworthy in the context of marital dissolution and re-partnering - two demographic events that one may have rated most likely to alter individual values. In this sense, our study nourishes the idea of deterministic forces underlying a gendered division of labour in the home.

\section{REFERENCES}

Akerlof, G. A.,Kranton, R. E. (2000) 'Economics and identity',Quarterly Journal of Economics, 115(3), 715-753.

Åström, J., Nakosteen, R.A., Westerlund, O.,Zimmer, M.A. (2009)'Twice chosen: Spouse matching and earnings among women in first and second marriages',Umeå Economic Studies 795, Umeå University, Department of Economics.

Axinn W. G., Thornton A. (1992) 'The Relationship between Cohabitation and Divorce: Selectivity or Causal Influence?’, Demography, 29 (3), 357-374.

Aughinbaugh, A. (2010) 'The effect of remarriage on women's labor supply', Journal of Population Economics, 23(4), 1151-1176. 
Becker, G. S., Landes, E. M.,Michael, R. T. (1977) 'An economic analysis of marital instability', The Journal of Political Economy, 85(6), 1141-1187.

Becker, G. S. (1973) 'A theory of marriage: Part I.', Journal of Political Economy, 81(4), 813-46.

Barg, M.,Beblo, M. (2012) 'Does "sorting into specialization" explain the differences in time use between married and cohabiting couples? An empirical application for Germany', Annals of Economics and Statistics (Annales d'Économie et de Statistique), 105/106, 127-152.

Baxter, J., Hewitt, B., Haynes, M. (2008) 'Life course transitions and housework: Marriage, parenthood, and time on housework', Journal of Marriage and Family, 70(2), 259-272.

Beblo, M.,Görges, L. (2016) 'On the nature of nurture. Gender differences in work preferences in East and West Germany, Working paper, Universität Hamburg.

$\mathrm{BiB}$, Bundesinstitut für Bevölkerungsforschung (2014) Eheschließende nach dem bisherigen Familienstand in Deutschland, 1955 bis 2012.

Bonnet, C., Solaz, A., Algava, E. (2010) 'Changes in labour market status surrounding union dissolution in France'. Population, 65(2), 251-284.

Bozon, M. (1991)'Women and the age gap between spouses: An accepted domination?' Population: An English Selection, 3, 113-148.

Brines, J. (1994) 'Economic dependency, gender and the division of labor at home', American Journal of Sociology, 100(3), 652-688.

Brines, J., Joyner, K. (1999) 'The ties that bind: Principles of cohesion in cohabitation and marriage', American Sociological Review, 64 (3), 333-355.

Chiswick, C. U., Lehrer, E. (1990) 'On marriage-specific human capital: Its role as a determinant of remarriage', Journal of Population Economics, 3(3), 193-213.

Cooke, L. P. (2006) "Doing” gender in context: Household bargaining and risk of divorce in Germany and the United States', American Journal of Sociology, 112(2), 442-472.

Dewilde, C.,Uunk, W. (2008) 'Remarriage as a way to overcome the financial consequences of divorce-A test of the economic need hypothesis for European women', European Sociological Review, 24(3), 393-407.

Duncan, G. J.,Hoffman, S. D. (1985). 'A reconsideration of the economic consequences of marital dissolution'. Demography, 22(4), 485-497.

Eurostat (2014). Scheidungen je 1000 Personen. http://epp.eurostat.ec.europa.eu/tgm/table.do?tab=table\&init=1\&language=de \&pcode=tps00013\&plugin=1 . Accessed 2014-12-09. 
Finnie, R. (1993) 'Women, men, and the economic consequences of divorce: Evidence from Canadian longitudinal data', Canadian Review of Sociology and Anthropology, 30(2), 205-241.

Fox L., Han W-J., Ruhm C., Waldfogel J. (2013) 'Time for children: Trends in the employment patterns of parents, 1967-2009', Demography 50, 25-49.

Gimenez-Nadal, JI,Sevilla-Sanz, A. (2012) 'Trends in time allocation: a cross-country analysis', European Economic Review 56, 1338-1359.

Hiller, D. V. (1984) 'Power dependence and division of family work'. Sex Roles, 10, 1003-1019.

Hook, J. L. (2010) 'Gender inequality in the welfare state: Sex segregation in housework, 19652003', American Journal of Sociology, 115(5), 1480-1523.

Ishii-Kuntz, M., Coltrane, S. (1992), 'Remarriage, stepparenting and household labor', Journal of Family Issues, 13(2), 215-233.

Jenkins, S. P.,O'Leary, N. C. (1995) 'Modelling domestic work time', Journal of Population Economics, 8(3), 265-279.

Johnson, W. R., Skinner, J. (1986), 'Labor supply and marital separation', The American Economic Review, 76(3), 455-469.

Konrad, K. A., Lommerud, K. E. (2000) 'The bargaining family revisited', Canadian Journal of Economics, 33(2), 471-487.

Manser, M., Brown, M. (1980) 'Marriage and household decision-making: A bargaining analysis', International Economic Review, 21(1), 31-44.

McElroy, M.B., Horney, M.J. (1981) 'Nash bargained household decisions', International Economic Review, 22(2), 333-349.

Nakosteen, R. A., Westerlund, O., Zimmer, M.A. (2004) 'Marital matching and earnings evidence from the unmarried population in Sweden', Journal of Human Resources, 39(4),1033-1044.

Ott, N. (1992). Intrafamily bargaining and household decisions. Springer: Berlin Heidelberg New York.

Ruggles, S. (1999) 'The rise of divorce and separation in the United States, 1880-1990' Demography, 34(4), 455-466.

Schulz, F. (2010) Verbundene Lebensläufe. Partnerwahl und Arbeitsteilung zwischen Ressourcenverhältnissen und traditionellen Geschlechterrollen, Wiesbaden.

Shafer, K., James, S. L. (2013) 'Gender and socioeconomic status differences in first and second marriage formation', Journal of Marriage and Family, 75(3), 544-564. 
Smock P. (1990), 'Remarriage Patterns of Black and White Women: Reassessing the Role of Educational Attainment', Demography 27(3), 467-473.

South, S. J., Spitze, G. D. (1994) 'Housework in marital and non marital households', American Sociological Review, 59, 327-347.

Sullivan, O. (1997) 'The division of housework among "remarried" couples', Journal of Family Issues, 18(2), 205-223.

Sullivan, O.,Gershuny, J.(2012) 'Relative human capital resources and housework: a longitudinal analysis', University of Oxford Sociology Working Papers, 2012-04.

Wagner G., Frick, J. R., Schupp, J. (2007) 'The German socio-economic panel study (SOEP): Scope, evolution and enhancements', Schmollers Jahrbuch, 1, 139-170.

West, C., Zimmerman, D. H. (1987) 'Doing gender', Gender \& Society, 1(2), 125-151.

Zhang, J., Liu, P.W. (2003) 'Testing Becker's prediction on assortative mating on spouses' wages', Journal of Human Resources, 38(1), 99-110. 


\section{Table 1a: Women's and men's characteristics in female unions}

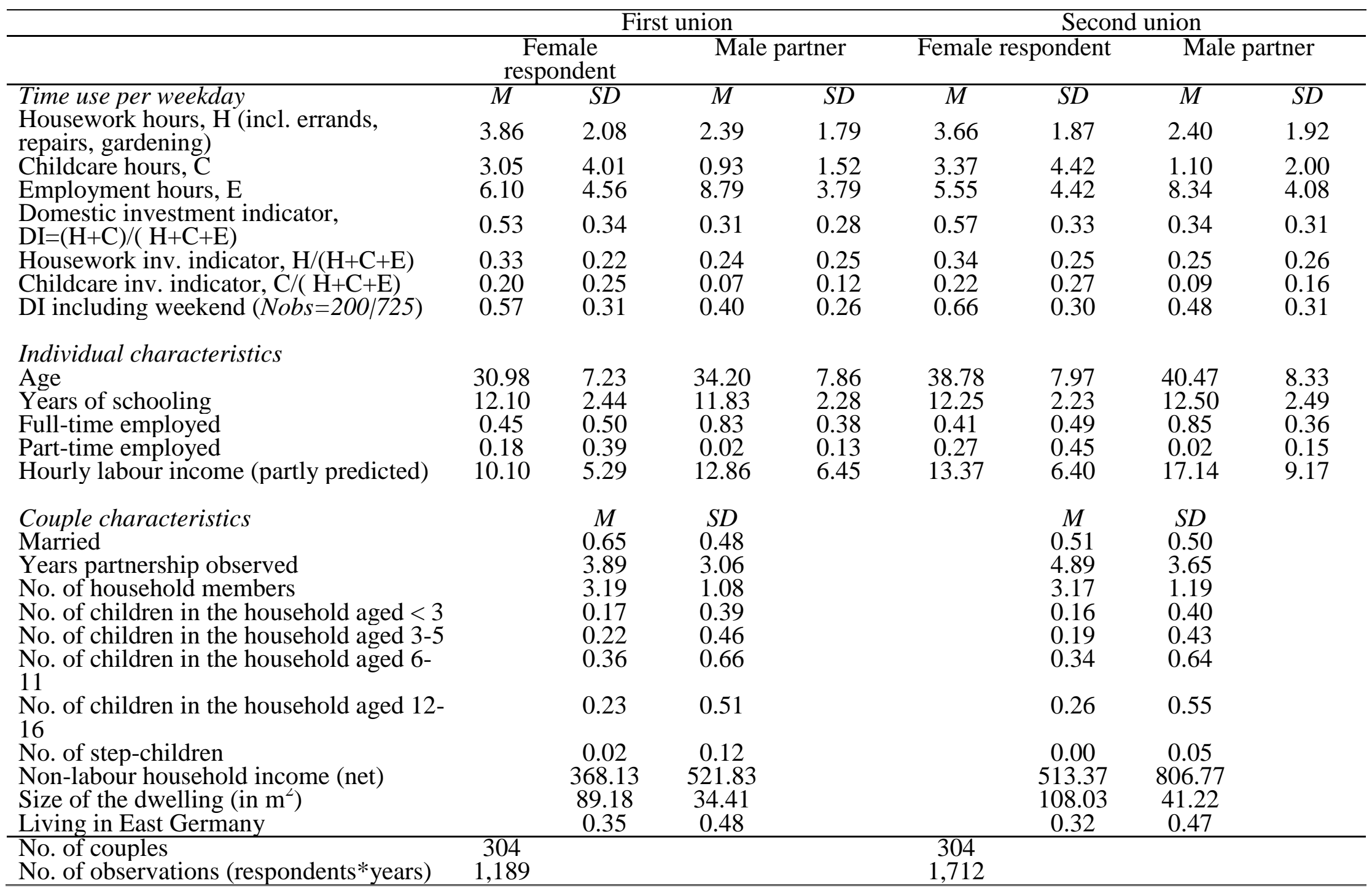

Source: Own calculations on GSOEP waves 1991 to 2012. Sample means are shown for all observation units of a couple where information on both partners is available. 
Table 1b: Women's and men's characteristics in male unions

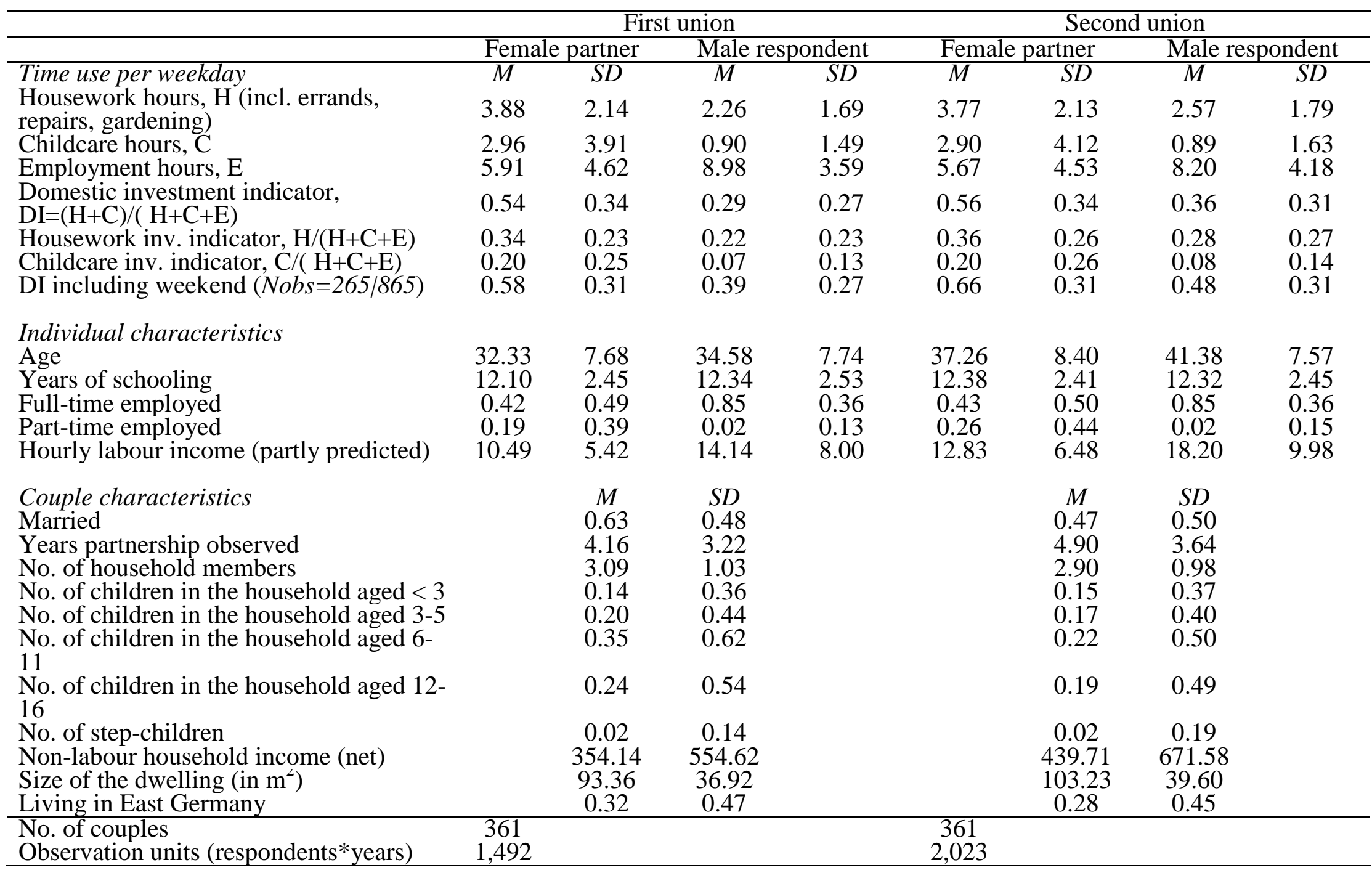

Source: Own calculations on GSOEP waves 1991 to 2012. Sample means are shown for all observation units of a couple where information on both partners is available. 
Table 2: Fixed effects estimation of relative domestic time use in women's second unions

\begin{tabular}{|c|c|c|c|c|c|c|c|c|}
\hline \multirow{2}{*}{$\begin{array}{l}\text { Dependent } \\
\text { variable = DI }\end{array}$} & \multicolumn{2}{|c|}{ Model 1} & \multicolumn{2}{|c|}{ Model 2} & \multicolumn{2}{|c|}{ Model 3} & \multicolumn{2}{|c|}{ Model 4} \\
\hline & $\begin{array}{l}\text { Female } \\
\text { resp. }\end{array}$ & $\begin{array}{l}\text { Male } \\
\text { partner }\end{array}$ & $\begin{array}{l}\text { Female } \\
\text { resp. }\end{array}$ & $\begin{array}{l}\text { Male } \\
\text { partner }\end{array}$ & $\begin{array}{l}\text { Female } \\
\text { resp. }\end{array}$ & $\begin{array}{l}\text { Male } \\
\text { partner }\end{array}$ & $\begin{array}{l}\text { Female } \\
\text { resp. }\end{array}$ & $\begin{array}{l}\text { Male } \\
\text { partner }\end{array}$ \\
\hline Second union & $\begin{array}{c}0.061 * * * \\
(0.019)\end{array}$ & $\begin{array}{c}0.040^{* *} \\
(0.018)\end{array}$ & $\begin{array}{l}0.059^{*} \\
(0.032)\end{array}$ & $\begin{array}{l}-0.029 \\
(0.025)\end{array}$ & $\begin{array}{c}0.069^{* *} \\
(0.032)\end{array}$ & $\begin{array}{l}-0.028 \\
(0.026)\end{array}$ & $\begin{array}{c}0.021 \\
(0.033)\end{array}$ & $\begin{array}{l}-0.085 \\
(0.037)\end{array}$ \\
\hline \multicolumn{9}{|l|}{ Individual charact. } \\
\hline Her age & & & $\begin{array}{c}0.000 \\
(0.004)\end{array}$ & $\begin{array}{c}0.008 * * * \\
(0.002)\end{array}$ & $\begin{array}{c}-0.008^{*} \\
(0.004)\end{array}$ & $\begin{array}{c}0.008^{* *} \\
(0.003)\end{array}$ & $\begin{array}{c}0.000 \\
(0.004)\end{array}$ & $\begin{array}{c}0.013 * * \\
(0.005)\end{array}$ \\
\hline Her wage & & & $\begin{array}{l}-0.000 \\
(0.003)\end{array}$ & $\begin{array}{c}-0.001 \\
(0.001)\end{array}$ & $\begin{array}{c}-0.001 \\
(0.002)\end{array}$ & $\begin{array}{l}-0.000 \\
(0.001)\end{array}$ & $\begin{array}{c}0.000 \\
(0.002)\end{array}$ & $\begin{array}{c}0.000 \\
(0.001)\end{array}$ \\
\hline \multicolumn{9}{|l|}{ Partner charact. } \\
\hline Partner's age & & & & & $\begin{array}{c}0.006^{* *} \\
(0.003)\end{array}$ & $\begin{array}{c}0.002^{* *} \\
(0.003)\end{array}$ & $\begin{array}{c}0.003 \\
(0.002)\end{array}$ & $\begin{array}{c}0.001 \\
(0.003)\end{array}$ \\
\hline Partner's wage & & & & & $\begin{array}{c}0.005^{* * *} * \\
(0.001)\end{array}$ & $\begin{array}{l}-0.003 \\
(0.002)\end{array}$ & $\begin{array}{c}0.002 * * * \\
(0.001)\end{array}$ & $\begin{array}{c}-0.002 \\
(0.002)\end{array}$ \\
\hline \multicolumn{9}{|l|}{ Couple background } \\
\hline Married & & & & & & & $\begin{array}{c}0.049 * * * \\
(0.018)\end{array}$ & $\begin{array}{c}0.020 \\
(0.017)\end{array}$ \\
\hline Yrs couple observed & & & & & & & $\begin{array}{c}0.002 \\
(0.004)\end{array}$ & $\begin{array}{c}-0.007 \\
(0.005)\end{array}$ \\
\hline \# children $0-2$ & & & & & & & $\begin{array}{c}0.307 * * * \\
(0.017)\end{array}$ & $\begin{array}{c}0.010 \\
(0.018)\end{array}$ \\
\hline \# children $3-5$ & & & & & & & $\begin{array}{c}0.144 * * * \\
(0.015)\end{array}$ & $\begin{array}{c}0.015 \\
(0.015)\end{array}$ \\
\hline \# children $6-11$ & & & & & & & $\begin{array}{c}0.061^{* * * *} \\
(0.013)\end{array}$ & $\begin{array}{c}0.002 \\
(0.014)\end{array}$ \\
\hline \# children $12-16$ & & & & & & & $\begin{array}{c}0.009 \\
(0.011)\end{array}$ & $\begin{array}{c}0.007 \\
(0.013)\end{array}$ \\
\hline \# step children & & & & & & & $\begin{array}{c}0.014 \\
(0.048)\end{array}$ & $\begin{array}{c}-0.011 \\
(0.049)\end{array}$ \\
\hline Dwelling size & & & & & & & $\begin{array}{c}0.000 \\
(0.000)\end{array}$ & $\begin{array}{c}-0.001 * * * \\
(0.000)\end{array}$ \\
\hline HH nonlab.inc./1000 & & & & & & & $\begin{array}{l}0.064^{*} \\
(0.016)\end{array}$ & $\begin{array}{c}0.118 * * * \\
(0.023)\end{array}$ \\
\hline East Germany & & & & & & & $\begin{array}{c}0.016 \\
(0.045)\end{array}$ & $\begin{array}{l}0.090 * \\
(0.050)\end{array}$ \\
\hline Constant & $\begin{array}{c}0.517 \\
(0.011) \\
\end{array}$ & $\begin{array}{c}0.307 \\
(0.011) \\
\end{array}$ & $\begin{array}{c}0.510 * * * \\
(0.103)\end{array}$ & $\begin{array}{c}.074 \\
(0.061) \\
\end{array}$ & $\begin{array}{c}0.495 * * * \\
(0.102)\end{array}$ & $\begin{array}{c}0.061 \\
(0.061)\end{array}$ & $\begin{array}{c}0.196 * * * \\
(0.108)\end{array}$ & $\begin{array}{c}-0.113 \\
(0.112)\end{array}$ \\
\hline R-sq overall & 0.004 & 0.002 & 0.003 & 0.000 & 0.013 & 0.004 & 0.309 & 0.040 \\
\hline $\begin{array}{l}\text { No. of observations } \\
\text { No. of couples }\end{array}$ & \multicolumn{8}{|c|}{$\begin{array}{c}2901 \\
304\end{array}$} \\
\hline
\end{tabular}


Table 3: Fixed effects estimation of relative domestic time use in men's second unions

\begin{tabular}{|c|c|c|c|c|c|c|c|c|}
\hline & \multicolumn{2}{|c|}{ Model 1} & \multicolumn{2}{|c|}{ Model 2} & \multicolumn{2}{|c|}{ Model 3} & \multicolumn{2}{|c|}{ Model 4} \\
\hline $\begin{array}{l}\text { Dependent } \\
\text { variable = DI }\end{array}$ & $\begin{array}{l}\text { Female } \\
\text { partner }\end{array}$ & $\begin{array}{l}\text { Male } \\
\text { resp. }\end{array}$ & $\begin{array}{l}\text { Female } \\
\text { partner }\end{array}$ & $\begin{array}{l}\text { Male } \\
\text { resp. }\end{array}$ & $\begin{array}{l}\text { Female } \\
\text { partner }\end{array}$ & $\begin{array}{l}\text { Male } \\
\text { resp. }\end{array}$ & $\begin{array}{l}\text { Female } \\
\text { partner }\end{array}$ & $\begin{array}{l}\text { Male } \\
\text { resp. }\end{array}$ \\
\hline Second union & $\begin{array}{l}0.038 * \\
(0.022)\end{array}$ & $\begin{array}{c}0.069 * * * \\
(0.013)\end{array}$ & $\begin{array}{l}-0.004 \\
(0.030)\end{array}$ & $\begin{array}{c}0.002 \\
(0.018)\end{array}$ & $\begin{array}{c}0.001 \\
(0.031)\end{array}$ & $\begin{array}{c}0.007 \\
(0.018)\end{array}$ & $\begin{array}{c}0.007 \\
(0.036)\end{array}$ & $\begin{array}{l}-0.032 \\
(0.029)\end{array}$ \\
\hline Individual charact. & & & & & & & & \\
\hline His age & & & $\begin{array}{c}0.004 \\
(0.003)\end{array}$ & $\begin{array}{c}0.007 * * * \\
(0.002)\end{array}$ & $\begin{array}{c}0.002 \\
(0.003)\end{array}$ & $\begin{array}{c}0.006 * * \\
(0.003)\end{array}$ & $\begin{array}{c}0.004 \\
(0.003)\end{array}$ & $\begin{array}{c}0.009 * * \\
(0.004)\end{array}$ \\
\hline His wage & & & $\begin{array}{c}0.002 \\
(0.001)\end{array}$ & $\begin{array}{c}0.000 \\
(0.001)\end{array}$ & $\begin{array}{c}-0.003 * * \\
(0.002)\end{array}$ & $\begin{array}{c}0.001 \\
(0.001)\end{array}$ & $\begin{array}{l}-0.002 * \\
(0.001)\end{array}$ & $\begin{array}{c}0.000 \\
(0.001)\end{array}$ \\
\hline Partner charact. & & & & & & & & \\
\hline Partner's age & & & & & $\begin{array}{c}0.003 \\
(0.004)\end{array}$ & $\begin{array}{c}0.002 \\
(0.002)\end{array}$ & $\begin{array}{c}0.005 \\
(0.005)\end{array}$ & $\begin{array}{c}0.003 \\
(0.002)\end{array}$ \\
\hline Partner's wage & & & & & $\begin{array}{c}0.002 * * \\
(0.001)\end{array}$ & $\begin{array}{l}-0.001 \\
(0.001)\end{array}$ & $\begin{array}{l}-0.000 \\
(0.001)\end{array}$ & $\begin{array}{l}-0.000 \\
(0.001)\end{array}$ \\
\hline Couple background & & & & & & & & \\
\hline Married & & & & & & & $\begin{array}{c}0.083 * * * \\
(0.018)\end{array}$ & $\begin{array}{l}-0.007 \\
(0.017)\end{array}$ \\
\hline Yrs couple observed & & & & & & & $\begin{array}{l}-0.004 \\
(0.005)\end{array}$ & $\begin{array}{c}-0.003 \\
(0.004)\end{array}$ \\
\hline \# children $0-2$ & & & & & & & $\begin{array}{c}0.337 * * * \\
(0.017)\end{array}$ & $\begin{array}{c}0.051 * * * \\
(0.015)\end{array}$ \\
\hline \# children $3-5$ & & & & & & & $\begin{array}{c}0.170 * * * \\
(0.015)\end{array}$ & $\begin{array}{c}0.021 \\
(0.014)\end{array}$ \\
\hline \# children 6-11 & & & & & & & $\begin{array}{c}0.107 * * * \\
(0.014)\end{array}$ & $\begin{array}{c}0.027 * * \\
(0.011)\end{array}$ \\
\hline \# children $12-16$ & & & & & & & $\begin{array}{c}0.044 * * * \\
(0.014)\end{array}$ & $\begin{array}{c}-0.017 \\
(0.012)\end{array}$ \\
\hline \# step children & & & & & & & $\begin{array}{c}-0.014 \\
(0.023)\end{array}$ & $\begin{array}{c}0.018 \\
(0.018)\end{array}$ \\
\hline Dwelling size & & & & & & & $\begin{array}{c}0.000 \\
(0.000)\end{array}$ & $\begin{array}{c}-0.001 * * * \\
(0.000)\end{array}$ \\
\hline HH nonlab.inc./1000 & & & & & & & $\begin{array}{c}0.068 * * * \\
(0.013)\end{array}$ & $\begin{array}{c}0.109 * * * \\
(0.017)\end{array}$ \\
\hline East Germany & & & & & & & $\begin{array}{c}0.032 \\
(0.055)\end{array}$ & $\begin{array}{l}0.099 * \\
(0.054)\end{array}$ \\
\hline Constant & $\begin{array}{c}0.528 \\
(0.013)\end{array}$ & $\begin{array}{c}0.289 \\
(0.008)\end{array}$ & $\begin{array}{c}0.379 * * * \\
(0.082)\end{array}$ & $\begin{array}{c}.036 \\
(0.061)\end{array}$ & $\begin{array}{c}0.386 * * * \\
(0.081)\end{array}$ & $\begin{array}{c}0.041 \\
(0.061)\end{array}$ & $\begin{array}{c}0.099 \\
(0.137) \\
\end{array}$ & $\begin{array}{c}-0.110 \\
(0.113)\end{array}$ \\
\hline R-sq overall & 0.000 & 0.012 & 0.000 & 0.003 & 0.006 & 0.003 & 0.324 & 0.083 \\
\hline $\begin{array}{l}\text { No. of observations } \\
\text { No. of couples }\end{array}$ & & & & & $\begin{array}{l}515 \\
61\end{array}$ & & & \\
\hline
\end{tabular}

Source: GSOEP waves 1991 to 2012. 
Table 4: Fixed effects estimation of different relative domestic time uses

\begin{tabular}{|c|c|c|c|c|c|c|c|c|}
\hline \multirow[b]{3}{*}{$\begin{array}{l}\text { Dep. var. = } \\
\text { DI }_{x}^{\text {f,m }}\end{array}$} & \multicolumn{4}{|c|}{ Women's second unions } & \multicolumn{4}{|c|}{ Men's second unions } \\
\hline & \multicolumn{2}{|c|}{ Childcare } & \multicolumn{2}{|c|}{ Housework } & \multicolumn{2}{|c|}{ Childcare } & \multicolumn{2}{|c|}{ Housework } \\
\hline & $\begin{array}{l}\text { Female } \\
\text { resp. }\end{array}$ & $\begin{array}{c}\text { Male } \\
\text { partner }\end{array}$ & $\begin{array}{l}\text { Female } \\
\text { resp. }\end{array}$ & $\begin{array}{c}\text { Male } \\
\text { partner }\end{array}$ & $\begin{array}{l}\text { Female } \\
\text { partner }\end{array}$ & $\begin{array}{l}\text { Male } \\
\text { resp. }\end{array}$ & $\begin{array}{l}\text { Female } \\
\text { partner }\end{array}$ & Male resp. \\
\hline Second union & $.057 * * *$ & $.032 * *$ & -.036 & $-.119 * * *$ & .026 & .012 & -.020 & -.044 \\
\hline $\begin{array}{l}\text { Individual } \\
\text { charact. }\end{array}$ & $\mathrm{Y}$ & Y & Y & $\mathrm{Y}$ & $\mathrm{Y}$ & $\mathrm{Y}$ & $\mathrm{Y}$ & Y \\
\hline Partner charact. & $\mathrm{Y}$ & $\mathrm{Y}$ & $\mathrm{Y}$ & $\mathrm{Y}$ & $\mathrm{Y}$ & $\mathrm{Y}$ & $\mathrm{Y}$ & $\mathrm{Y}$ \\
\hline Couple charact. & $\mathrm{Y}$ & $\mathrm{Y}$ & $\mathrm{Y}$ & $\mathrm{Y}$ & $\mathrm{Y}$ & $\mathrm{Y}$ & $\mathrm{Y}$ & $\mathrm{Y}$ \\
\hline R-sq overall & 0.611 & 0.265 & 0.059 & 0.066 & 0.631 & 0.281 & 0.064 & 0.077 \\
\hline $\begin{array}{l}\text { No. of obs. } \\
\text { No. of couples }\end{array}$ & & & $\begin{array}{l}01 \\
04\end{array}$ & & & & $\begin{array}{l}515 \\
361\end{array}$ & \\
\hline
\end{tabular}

*** indicates statistical significance at the $1 \%$ level, **at 5\%, * at $10 \%$.

Specification of Model 4.

Source: GSOEP waves 1991 to 2012. 
Table 5: Fixed effects estimation with subgroup interaction effects on different relative domestic time uses in women's second unions (respondents' time use)

\begin{tabular}{|c|c|c|c|c|c|c|c|c|}
\hline \multirow[b]{2}{*}{ Dep. var. $=$ DI $^{\mathrm{f}}$} & \multicolumn{4}{|c|}{ Childcare } & \multicolumn{4}{|c|}{ Housework } \\
\hline & $\begin{array}{l}\text { Married } \\
1^{\text {st }} \text { union }\end{array}$ & $\begin{array}{l}\text { Children } \\
1^{\text {st }} \text { union }\end{array}$ & $\begin{array}{l}\text { Union } \\
\text { gap }>=3\end{array}$ & $\begin{array}{l}\text { High } \\
\text { educ. }\end{array}$ & $\begin{array}{l}\text { Married } \\
1^{\text {st }} \text { union }\end{array}$ & $\begin{array}{l}\text { Children } \\
1^{\text {st }} \text { union }\end{array}$ & $\begin{array}{l}\text { Union } \\
\text { gap }>=3\end{array}$ & $\begin{array}{l}\text { High } \\
\text { educ. }\end{array}$ \\
\hline Second union & $\begin{array}{c}.068 * * * \\
(.019) \\
\end{array}$ & $\begin{array}{c}.075^{* * *} \\
(.017) \\
\end{array}$ & $\begin{array}{l}.041 * * \\
(.018) \\
\end{array}$ & $\begin{array}{l}.048 * * * \\
(.017)\end{array}$ & $\begin{array}{c}-.037 \\
(.0295) \\
\end{array}$ & $\begin{array}{l}-.039 \\
(.029) \\
\end{array}$ & $\begin{array}{l}-.031 \\
(.027) \\
\end{array}$ & $\begin{array}{l}-.028 \\
(.026) \\
\end{array}$ \\
\hline $\begin{array}{l}\text { Subgroup } \\
\text { interaction }\end{array}$ & $\begin{array}{c}.053 * * * \\
(.019)\end{array}$ & $\begin{array}{c}.078 * * * \\
(.021)\end{array}$ & $\begin{array}{l}.002 \\
(.022)\end{array}$ & $\begin{array}{l}.040 * * \\
(.020)\end{array}$ & $\begin{array}{l}.002 \\
(.023)\end{array}$ & $\begin{array}{l}.009 \\
(.027)\end{array}$ & $\begin{array}{l}-.016 \\
(.025)\end{array}$ & $\begin{array}{l}-.78 * * \\
(.036)\end{array}$ \\
\hline Individual charact. & $\mathrm{Y}$ & $\mathrm{Y}$ & $\mathrm{Y}$ & $\mathrm{Y}$ & $\mathrm{Y}$ & $\mathrm{Y}$ & $\mathrm{Y}$ & Y \\
\hline Partner charact. & $\mathrm{Y}$ & Y & $\mathrm{Y}$ & Y & $\mathrm{Y}$ & Y & $Y$ & $Y$ \\
\hline Couple charact. & $\mathrm{Y}$ & $\mathrm{Y}$ & $\mathrm{Y}$ & $\mathrm{Y}$ & $\mathrm{Y}$ & $\mathrm{Y}$ & $\mathrm{Y}$ & $\mathrm{Y}$ \\
\hline R-sq overall & 0.590 & 0.575 & 0.600 & 0.602 & 0.058 & 0.059 & 0.056 & 0.063 \\
\hline $\begin{array}{l}\text { No. of } \\
\text { observations }\end{array}$ & \multicolumn{8}{|c|}{2,910} \\
\hline No. of couples & \multicolumn{8}{|c|}{304} \\
\hline
\end{tabular}

*** indicates statistical significance at the $1 \%$ level, ** at 5\%, * at 10\%.

Specification of Model 4.

Source: GSOEP waves 1991 to 2012.

Table 6: Fixed effects estimation with subgroups' interaction effects on different relative domestic time uses in men's second unions (respondents' time use)

\begin{tabular}{|c|c|c|c|c|c|c|c|c|}
\hline \multirow[b]{2}{*}{ Dep. var. $=$ DI $^{\mathrm{f}}$} & \multicolumn{4}{|c|}{ Childcare } & \multicolumn{4}{|c|}{ Housework } \\
\hline & $\begin{array}{l}\text { Married } \\
1^{\text {st }} \text { union }\end{array}$ & $\begin{array}{l}\text { Children } \\
1^{\text {st }} \text { union } \\
\end{array}$ & $\begin{array}{c}\text { Union } \\
\text { gap }>=3\end{array}$ & $\begin{array}{l}\text { High } \\
\text { educ. }\end{array}$ & $\begin{array}{l}\text { Married } \\
1^{\text {st }} \text { union }\end{array}$ & $\begin{array}{l}\text { Children } \\
1^{\text {st }} \text { union }\end{array}$ & $\begin{array}{l}\text { Union } \\
\text { gap }>=3\end{array}$ & $\begin{array}{l}\text { High } \\
\text { educ. }\end{array}$ \\
\hline Second union & $\begin{array}{c}.017 \\
(.011)\end{array}$ & $\begin{array}{l}.026 * * \\
(.010)\end{array}$ & $\begin{array}{c}.002 \\
(.011)\end{array}$ & $\begin{array}{l}.006 \\
(.010)\end{array}$ & $\begin{array}{c}-.067 * * \\
(.027)\end{array}$ & $\begin{array}{c}-.047 * \\
(.028)\end{array}$ & $\begin{array}{l}-.041 \\
(.0276)\end{array}$ & $\begin{array}{l}-.041 \\
(.027)\end{array}$ \\
\hline $\begin{array}{l}\text { Subgroup } \\
\text { interaction }\end{array}$ & $\begin{array}{l}-.0272 * \\
(.014)\end{array}$ & $\begin{array}{c}-.053 * * * \\
(.013)\end{array}$ & $\begin{array}{l}.026 * * \\
(.013)\end{array}$ & $\begin{array}{l}-0.001 \\
(0.027)\end{array}$ & $\begin{array}{l}.060^{* * *} \\
(.026)\end{array}$ & $\begin{array}{l}.000 \\
(.030)\end{array}$ & $\begin{array}{l}-.027 \\
(.027)\end{array}$ & $\begin{array}{c}-.072 \\
(. \\
035)^{* *}\end{array}$ \\
\hline Individual charact. & Y & Y & Y & Y & Y & Y & Y & Y \\
\hline Partner charact. & $\mathrm{Y}$ & Y & Y & $\mathrm{Y}$ & Y & $\mathrm{Y}$ & Y & Y \\
\hline Couple charact. & $\mathrm{Y}$ & $\mathrm{Y}$ & $\mathrm{Y}$ & Y & Y & Y & Y & Y \\
\hline R-sq overall & 0.280 & 0.027 & 0.283 & 0.280 & 0.075 & 0.071 & 0.065 & 0.074 \\
\hline $\begin{array}{l}\text { No. of } \\
\text { observations }\end{array}$ & \multicolumn{8}{|c|}{3,515} \\
\hline No. of couples & \multicolumn{8}{|c|}{361} \\
\hline
\end{tabular}

*** indicates statistical significance at the $1 \%$ level, $* *$ at $5 \%, *$ at $10 \%$.

Specification of Model 4.

Source: GSOEP waves 1991 to 2012. 


\section{FIGURE}

Figure 1: Domestic investment indicator, DI, before breakup (left) and after re-partnering (right)
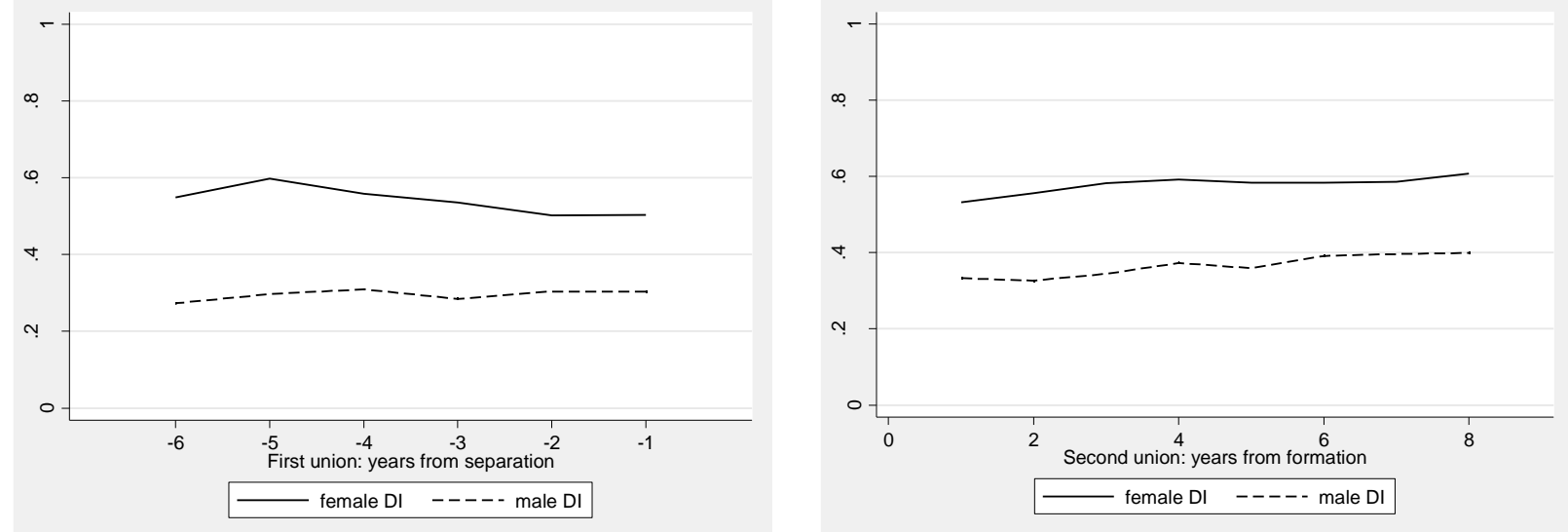

Source: GSOEP waves 1991 to 2012. 
